This Festschrift is dedicated to

\title{
Bogdan Bojarski and Kazimierz Gęba
}

honouring over 50 years of their influential and diverse accomplishments in Differential Equations,

Nonlinear Analysis and Algebraic Topology

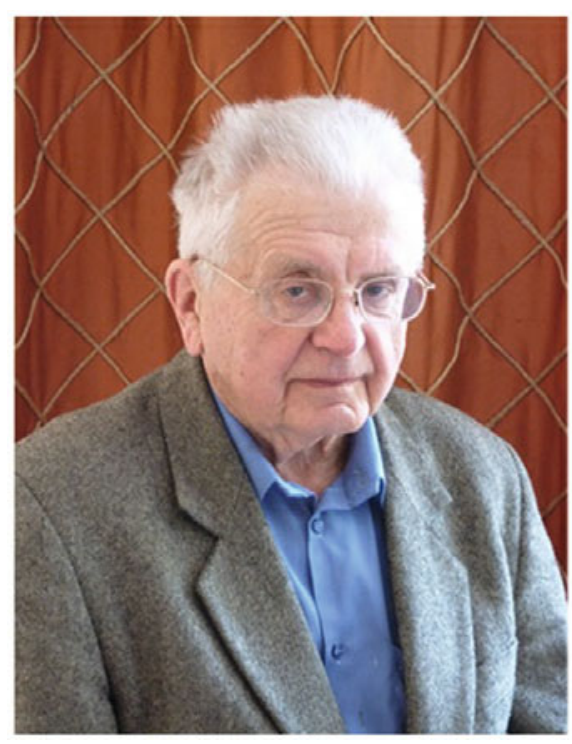

Bogdan Bojarski

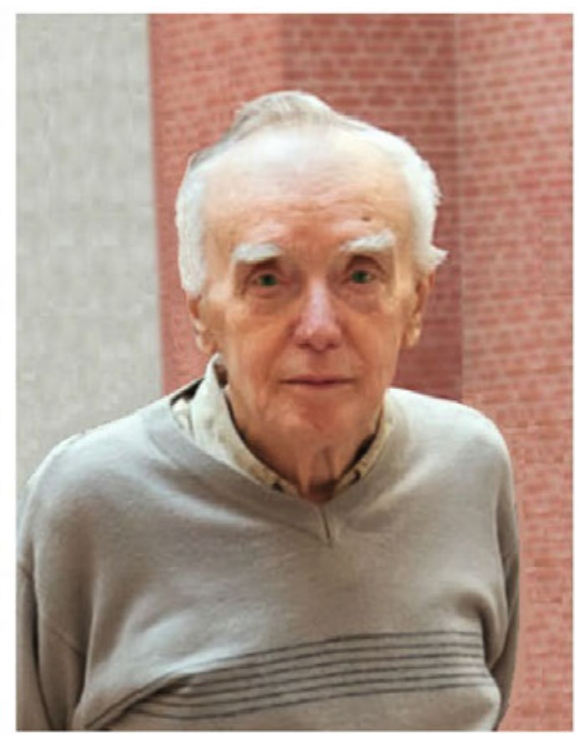

Kazimierz Gęba 